DOI: 10.15503/onis2014-141-145

\title{
Peugiem i purpurą albo Polska Ludowa jako monarchia
}

\author{
Piotr Kuligowski, Piotr.kuligowski.1990@gmail.com \\ Uniwersytet im. A. Mickiewicza w Poznaniu \\ Ul. Wieniawskiego 1, 61-712 Poznań
}

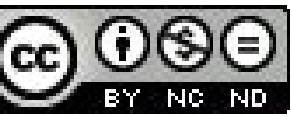

\section{STRESZCZENIE}

Artykuł dotyczy monarchistycznych koncepcii Polski Ludowej. O Polsce Ludowej na polskiej lewicy i centrolewicy pisano i dyskutowano przynajmniej od 1905 r., a koncepcje monarchistyczne były niszowe wśród jej wyobrażeń. Pojawiły się one jedynie w programie Związku Młodej Polski Ludowej w 1907 r. oraz w analogicznym dokumencie Zjednoczenia Ludowego z $1917 \mathrm{r}$. Pierwszy z tych tekstów jest bardziej socjalny w sferze społecznej, drugi - nieco bardziej zachowawczy. Oba są jednak świadectwem chłopskiego przywiązania do instytucji monarchii, które zniknęło ostatecznie w okresie międzywojennym.

Słowa kluczowe: chłopi, demokracja, monarchia, Polska Ludowa, program

With plow and purple - Poland of the People as monarchy

\section{Abstract}

The article is about monarchist conceptions of People's Poland. Polish left-wing and center-left were writing and were discussing a People's Poland since at least 1905, but conceptions of monarchy were niche ideas. They ocurred only in the program of the Association of Young People's Poland in 1907 and in an analogical document of the Union of People from 1917. The First text is more welfare in social things, the second - little more conservative. However both are the proof, that peasants were attached to monarchy. This attachment disappeared in the interwar period.

Key words: democracy, monarchy, peasants, People's Poland, program

Temat tekstu osobie słabo orientującej sięw dziejach polskiej lewicy może nasuwać skojarzenie z czymś, co Jerzy Topolski określałjako „podejście kontrfaktyczne” ${ }^{\prime 1}$ a co bywa określane mianem „historii alternatywnej”. Artykuł jednak bynajmniej nie ma na celu stawiania pytań z cyklu „Co by było, gdyby...”. Bo choć termin „Polska Ludowa” w powszechnej świadomości kojarzy się z rzeczywistym bytem państwowym z lat 1945-89 (choć istniejącym de iure dopiero od 1952 r.), to nie jest to jedyny poprawny desygnat tego pojęcia.

„Polska Ludowa” może mieć zatem znaczenie trojakie. Pierwsze nakreślono powyżej. Drugie stosunkowo niedawno nadała jej popkultura. Polska Ludowa jest tu więc nową gwiazdą kultury masowej, o czym świadczą rozmaite trendy, np. facebookowy profil Born in the PRL ma prawie 300 tys. polubien'², a w wielu miastach Polski istnieją kluby, nawiązujące stylistyką do PRL (gdański Polmozbytclub, poznański Proletaryat). I wreszcie w znaczeniu trzecim Polska Ludowa to całokształt programów, wyobrażeń, mitów ${ }^{3}$ i wizji całościowej przebudowy ustroju, snutych w środowiskach lewicowych i centrolewicowych co najmniej od 1905 r. ${ }^{4}$. Wtedy to właśnie ukazała się pierwsza odezwa Polskiego Związu Ludowego, w której prawdopodobnie po raz pierwszy użyto zbitki „Polska Ludowa” ${ }^{\prime \prime}$.

Rok 1905 przyniósł - obok rewolucji, która wstrząsnęła posadami carskiej Rosji - umasowienie głównych ruchów politycznych: narodowego, ludowego i socjalistycznego. O ile bowiem jeszcze u schyłku XIX w. były one reprezentowane przez inteligentów (dziennikarzy, nauczycieli, księży) i stosunkowo jeszcze nieliczne grupy działaczy, o tyle w $1905 \mathrm{r}$.

1 J. Topolski, Śzwiat bez historii, Poznań 1998, s. 23.

2 BORN IN THE PRL, https://www.facebook.com/BornInThePRL?fref=ts, 1.12.2013.

3 "Mit" jest tu rozumiany - za francuskim syndykalistą Georgem Sorelem - jako spoiwo polityczne warstw pozbawionych podmiotowości, które będzie generować nadzieje i postawy. Zob. P. Laskowski, Szkice z dziejów anarchizmu, Warszawa 2007, s. 406.

4 Paralelne w swej wymowie projekty, które równie jednoznacznie sytuowały suwerena w państwie polskim, pojawiały się już dużo wcześniej. W roku 1848 Fryderyk Engels pisał o „Polsce demokracii chłopskiej”, a w 1856 r. International Association, zrzeszające także socjalistów polskich, posłużyło się pojęciem „Rzeczpospolitej Powszechnej Ludowładczo-Społecznej”. Zob. A. Ciołkosz i L. Ciołkosz, Zarys dziejów socjalizmu polskiego, T. I, Londyn 1966, s. 320, 468-469.

5 Pierwsza programowa odezwa Polskiego Zwiazku Ludowego, http://lewicowo.pl/pierwsza-programowa-odezwa-polskiego-zwiazkuludowego/, 1.12.2013.

OGRODY NAUK I SZTUK NR 2014 (4) 
przeszły błyskawiczny rozrost sprawiajacc, że nowoczesna polityka trafiła pod strzechy ${ }^{6}$. W tym kontekście narodziny koncepcji Polski Ludowej to artykulacja chęci przeprowadzenia całościowej modernizacji, dostosowanej do specyfiki miejscowych, środkowoeuropejskich, ruralnych uwarunkowań?

W toku czterech dekad, od swych narodzin do wcielenia w życie przez komunistów, pojęciu Polski Ludowej nadawano bardzo różny kontekst - od postrzegania jej jako państwa głęboko zdemokratyzowanego (postulowano nawet obieralność sędziów $w^{8}$ ) po koncepcje monarchistyczne. Co warte podkreślenia, terminem tym nie posługiwali się działacze Komunistycznej Partii Polski, gdyż był dla nich za mało radykalny („ludowa”, a nie „radziecka” czy „komunistyczna”) i nazbyt nacechowany patriotyzmem.

Koncepcje monarchistyczne Polski Ludowej nie były zbyt popularne. Najprawdopodobniej powstały nie więcej niż dwa tego typu programy. Pierwszym z nich jest dokument Związku Młodej Polski Ludowej, który ukazał się w $1907 \mathrm{r}$. w nielegalnej broszurze, sygnowanej nazwą „Siewby" - postępowego pisma ludowego, wydawanego w Thuszczu na Mazowszu w latach 1906-1908. Miał on wyrażać poglądy tego środowiska, którego członków nazywano „,iewbiarzami”. Prawdopodobnie autorem tekstu lub jego głównych tez jest ks. Antoni Szech (Izydor Kajetan Wystouch) ${ }^{9}$. Drugi tekst, w którym postulowano utworzenie Polski Ludowej jako monarchii, wyszedł ze środowiska Zjednoczenia Ludowego. Była to chłopska organizacja zachowawcza, popierająca Radę Regencyjna, powstała w lutym 1917 r. z połączenia Narodowego Związku Chłopskiego, Polskiego Związku Ludowego i Partii Ludowej. W październiku 1918 r. ZL opuściła grupa bardziej postępowo nastawionych działaczy, a pozostali przekształcili się w Polskie Zjednoczenie Ludowe ${ }^{10}$.

Oba programy różnią się w kwestiach technicznych. Ten z 1907 r. jest znacznie obszerniejszy, ale i mniej konkretny, gdyż zawiera bardzo wiele apostrof i fragmentów silnie nacechowanych emocjonalnie. Wynika to zapewne z faktu, że wydatny wpływ na jego kształt miał wspomniany A. Szech, który bywa uznawany za twórcę polskiej wersji teologii wyzwolenia, czyli syntezy postulatów socjalistycznych z chrześcijaństwem ${ }^{11}$. Tekst przypomina zatem manifesty, tworzone przez niektórych emigrantów popowstaniowych we Francji w latach czterdziestych XIX w. ${ }^{12}$. Nie oznacza to jednak, że był archaiczny. Wymowa dokumentu zdaje się wynikać raczej z faktu dość zbliżonych warunków powstania - zarówno bowiem przegrane powstanie listopadowe, jak i fiasko rewolucji z 1905 r. było gorzką pigułką dla osób weń zaangażowanych i zapewne, w obliczu niemożności zmiany sytuacji ziemskimi, ludzkimi metodami, skłaniało ich do bardziej metafizycznych, transcedentalnych poszukiwań. Zarazem jednak bardzo silne akcenty religijne i moralizatorskie sprzężone są tu z daleko idacymi postulatami reform społecznych i socjalnych.

W zupełnie odmiennych, choć niezbyt przecież odległych czasowo warunkach, powstawał program ZL. Rok 1917 to wszak okres wielkich zmian - na wschodzie nastroje rewolucyjne, na ziemiach polskich coraz wyraźniejsze poczucie, że niepodległość to kwestia najbliższych miesięcy. W takich okolicznościach program ZL uderza lakonicznością i umiarkowaniem, będąc w dużej mierze przeciwieństwem wizji monarchistycznej Polski Ludowej, o dekadę wcześniejszej.

Program ZMPL zawiera tezy, charakterystyczne dla agrarnych nurtów socjalizmu. W części pierwszej, która stanowi ponurą diagnozę rozbiorowej rzeczywistości, zawiera on przede wszystkim wiele prostych, niewyszukanych tez („Nam Polakom narodem niewolników byćnie wolno!"133), stanowiąc raczej rodzaj bojowego manifestu. Dalszy ciąg tekstu zawiera postulaty pozytywne, podzielone na kategorię polityczna, kulturalną i ekonomiczną. Na podobne segmenty podzielony jest program ZL, który jednakże nie posiada jakiegokolwiek wprowadzenia i pod względem treści jest ograniczony do enumeratywnego wymienienia dążeń organizacji.

Pod względem politycznym dokument programowy ZMPL zawiera obok siebie zarówno dezyderaty fantasmagoryczne, jak i zupełnie realne. Widać tu wyraźnie element, który charakteryzował polską lewicę przez cały XIX w., czyli

6 K. Piskała, Zapomniana rewolucja, [w:] W. Marzec, K. Piskała (red.), Rewolucja 1905. Przewodnik Krytyki Politycznej, Łódź 2013, s. 39.

7 Wincenty Witos wspomina, że powstały 7.11.1918 r. rząd (który w swym programie głosił powstanie Polski Ludowej) deklarował odżegnanie się od wzorców wschodnich i zachodnich. Zob. W. Witos, Moje wspomnienia. Część II, Warszawa 1990, s. 37.

8 Zob. 1915, Warszawa, Program Związu Chtopskiego, [w:] K. Dunin-Wąsowicz, St. Kowalczyk, J. Molenda, W. Stankiewicz (red.), Materiały źródtowe do historii polskiego ruchu ludowego, T. I, Warszawa 1966, s. 393.

9 1907, styczé, Program pt. „Zwizzek Młodej Polski”, opracowany przez grupę ludowców skupiony wokót pisma „Siewba", [w:] K. Dunin-Wąsowicz, St. Kowalczyk, J. Molenda, W. Stankiewicz (red.), dz. cyt., s. 247.

10 1917, Warszawa, Program Zjednoczenia Ludowego, [w:] K. Dunin-Wąsowicz, St. Kowalczyk, J. Molenda, W. Stankiewicz (red.), dz. cyt., s. 428

11 R. Okraska, Za szcześćie wasze i nasze, czyli polska teologia wyzwolenia, http:/lewicowo.pl/za-szczescie-wasze-i-nasze-czyli-polska-teologiawyzwolenia/, 1.12.2013.

12 Podobną wymowę mają choćby artykuły Ludwika Królikowskiego czy Zenona Świętosławskiego.

13 1907, styczeń..., dz. cyt., s. 233. 
syntezę patriotyzmu i internacjonalizmu ${ }^{14}$. Oto bowiem anonimowy autor postuluje odrodzenie niepodległej Polski (ma być „ludowa - wolna - niepodległa - zjednoczona” ${ }^{\prime 15}$ ), ale jednocześnie domaga się federacji z Litwą i Rusia, czyli w istocie przywrócenia kształtu państwa sprzed 1772 r. Jest to jednak określone jako postulat „na jutro”. Celem bardziej odległym był związek wszystkich ludów ${ }^{16}$, które zamieszkują terytoria zaborców, a ideałem - federacja ogólnoeuropejska, która „da możność narodom Europy zjednoczonymi siłami osiągnięcia najwyższych zadań dziejowych ludzkości"17. Po raz kolejny widać tu bardzo wyraźne podobieństwo do koncepcji niektórych polskich socjalistów sprzed kilku dekad, którzy nawoływali do solidarnej wojny ludów przeciwko europejskim despotom ${ }^{18}$.

Autor programu ZMPL nie jest jednak w swym uniwersaliźmie i pewnym naiwnym idealiźmie oderwany od rzeczywistości. Dlatego obok wybiegania w przyszłość tworzy postulaty „na dziś”. W tej sferze punktem wyjścia jest dla niego Królestwo Polskie, a zatem osiagnięcie stanu sprzed powstania styczniowego. Chodzi więc o powołanie w Warszawie polskiego Sejmu ustawodawczego, na czele którego stanąłby król, rządzący dziedzicznie, ale ograniczony konstytucją. Celem jest zatem osiagnięcie autonomii ${ }^{19}$.

W sferze restauracji władzy królewskiej bardziej radykalny w swej wymowie jest program ZL. Jego autorzy postulowali utworzenie w wyzwolonej Polsce monarchii konstytucyjnej z dziedziczną dynastią królewską. Pisano, że „Zjednoczenie Ludowe pragnie silnego rządu, opartego na sprawiedliwym ustroju, oraz silnej władzy królewskiej, której majestatu po długich latach niewoli z wytęsknieniem oczekuje ${ }^{220}$. Wydaje się więc, że dla ZL akceptowalna byłaby silna, autorytarna władza.

Oba dokumenty programowe są mniej więcej zgodne w zakresie głoszonych postulatów kulturalnych, choć program ZMPL przedstawia je w sposób bardziej rozbudowany i szczegółowy. W dokumencie z 1907 r. pisano zatem wprost: "»Nieść do narodu oświaty kaganek « - to hasło dziś najszczytniejsze!"²1. Postulaty oscylują tu zatem wokół kwestii polskiej, bezpłatnej edukacji na wszystkich szczeblach, organizowania uniwersytetów ludowych, otwierania burs dla uczniów z prowincji etc. Nie pominięto tu także idei podniesienia kultury agrarnej poprzez zakładanie „szkół rolniczych, stowarzyszeń oświatowych, kółek rolniczych, wystaw gospodarczych, wzorowych gospodarstw, stacji doświadczalnych itp."22. Autorzy programu ZL ograniczyli się w tym zakresie li tylko do ogólnych stwierdzeń dotyczących bezpłatności i obowiązkowości edukacji, która winna mieć charakter narodowy i katolicki²3.

Wreszcie oba programy sporo dzieli pod względem zagadnień gospodarczych. Bardziej radykalny w tej sferze jest dokument ZMPL. Tekst ten zawiera przede wszystkim postulaty odnoszące się do włościan, czyli wywłaszczenie „na rzecz ludu" wielkich majątków ziemskich (acz za odszkodowaniem) czy zniesienie wewnętrznych barier taryfowych i celnych, hamujących rozwój rolnictwa. Istotną cechą gospodarki Polski Ludowej w jej „siewbiarskiej” wizji z 1907 r. miał być "postępowy”, czyli progresywny, system podatkowy. Wiele punktów tegoż programu odnosi się również do wprowadzenia rozlicznych osłon socjalnych, np. zniesienia pracy w nocy, zniesienia pracy dzieci, wprowadzenia powszechnych ubezpieczeń czy płacy minimalnej ${ }^{24}$. Znacznie bardziej powściągliwe dążenia prezentowało ZL. Mimo chęci parcelacji największych majątków ziemskich czy zapowiedzi popierania przez państwo spółdzielczości mowa tu jednocześnie o konieczności dopełnienia instytucjonalnego systemu zabezpieczeń społecznych prywatną działalnością charytatywną

Jak wspomniano, koncepcje monarchistyczne są całkowitą niszą wśród wyobrażeń Polski Ludowej, snutych na przestrzeni czterech dekad w środowiskach lewicy i centrolewicy. Poprzez uczestnictwo w Centrolewie, którego ostrze wymierzone było w sanacyjny autorytaryzm, środowiska ludowe i inne, szermujące pojęciem „Polski Ludowej” udowodniły swe przywiązanie do zasad demokracji. Wydaje się więc, że koncepcje, które były podmiotem niniejszego tekstu, u pro-

\footnotetext{
14 Choć mimo deklaracji o poszanowaniu wszystkich narodów pada tu jednoznaczne stwierdzenie o tym, że ZMPL „Zwalczać jednak gorąco będzie tych Żydów i te grupy żydowskie, które wyzyskiem polskiego narodu żyją". Tamże, s. 236.

15 Tamże, s. 237.

16 Ludy są tutaj oczywiście rozumiane jako grupy społeczne pozbawione podmiotowości politycznej.

17 Tamże.

18 Podobne koncepcje snuł np. Adam Mickiewicz w Księgach narodu i pielgrzymstwa polskiego („O wojnę powszechną za wolność ludów prosimy cię, panie, amen”). A. Mickiewicz, Księgi narodu i pielgrzymstwa polskiego, Warszawa 1986, s. 112

19 1907, styczeń..., dz. cyt., s. 238

20 1917, Warszawa..., dz. cyt., s. 426

211907, styczeń..., dz. cyt., s. 239

22 Tamże, s. 240.

23 1917, Warszawa..., dz. cyt., s. 427.

24 1907, styczeń..., dz. cyt., s. 241-245.

25 1917, Warszawa..., dz. cyt., s. 427-428.
}

OGRody NAUK I SZTUK NR 2014 (4) 
gu XX w. stanowiły już w dużej mierze relikt przemijających chłopskich wyobrażeń. By więc pełniej zrozumieć zawarte w nich dążenia, należy sięgnąc po źródła pamiętnikarskie.

Wincenty Witos, ukazując swą młodość (czyli lata siedemdziesiąte i osiemdziesiąte XIX w.) wspomina, że chłopi wszelką „wywrotowość" uznawali za coś, co raczej przyniesie nieszczęścia, niż zmiany in plus. Tadeusza Kościuszkę uznawali za zbrodniarza, a Napoleona Bonaparte - za modelowy przykład nieszczęść, który spotka każdego, kto ośmieli się sprzeciwić odwiecznej władzy rosyjskiego cara, wyobrażanego jako olbrzym w złotej zbroi ${ }^{26}$. Chłopi zreszta, jak wspominał W. Witos, czuli niechęć do polskich uroczystości, gdyż mieli w pamięci kilkuwiekową pańszczyznę, zniesioną dopiero przez cesarza ${ }^{27}$. Dlatego też galicyjska wieś uznawała Franciszka Józefa za wcielenie mądrości i sprawiedliwości. Chłopi szli więc chętnie do wojska i płacili podatki bez ociagania się uznając, że cesarz wspomógłby ich w niedoli, gdyby tylko o niej wiedział. Za ową niewiedzę obwiniano panów sądząc, że to oni separują monarchę od ludu ${ }^{28}$.

W podobnym świetle światopogląd chłopów z Mazowsza z początków XX w. przedstawia historyk Adam Czesław Dobroński. Jego zdaniem rewolucja z lat 1905-1907 przyniosła pewną radykalizację wsi, która - poprzez organizowanie nielegalnych zebrań, kolportaż prasy czy uznanie T. Kościuszki za bohatera - stopniowo przestawała obawiać się carskiej władzy ${ }^{29}$. Bynajmniej jednak nie wiązało się to z jednoczesnym spadkiem notowań samego cara. Na dziesięć lat przed odzyskaniem niepodległości wśród chłopów wciąż zjawiskiem dość powszechnym pozostawał lojalizm i wiara w dobrego cara ${ }^{30}$. Najwidoczniej wciąż jeszcze trudno im było wyobrazić sobie w praktyce system inny od monarchistycznego. Nawet w pierwszych dniach listopada 1918 r. chłopi z Lubelszczyzny, błędnie interpretując powstanie Tymczasowego Rządu Ludowego Republiki Polskiej, rozsiewali plotki o rzekomym wyborze polskiego króla ${ }^{31}$.

Na monarchistyczne koncepcje Polski Ludowej można zatem spoglądać przez szerszy pryzmat. Interesujących spostrzeżeń dostarczają tu dwaj brytyjscy marksizujący historycy, Rodney Howard Hilton i Harold Fagan, którzy analizują chłopskie bunty i przeobrażenia gospodarki feudalnej w kapitalistyczną. W swej książce, poświęconej powstaniu Wata Tylera z 1381 r., ukazują oni czternastowiecznych chłopów jako zwolenników monarchii ludowej, co oznacza, że - podobnie jak chłopi galicyjscy z pamiętnika W. Witosa - uznawali oni króla za działającego w ich imieniu ${ }^{32}$. Wydaje się więc, że dążenia do tego rodzaju ludowych czy socjalnych monarchii mogły być obecne wszędzie tam, gdzie następowała transformacja z feudalizmu w kapitalizm. A że Rzeczpospolita przeszła w XV w. refeudalizację, a reformy rolnej w Polsce dokonali dopiero komuniści w wieku XX, to nic dziwnego, że formułowane przez tutejszych chłopów koncepcje mogły być w najogólniejszym przynajmniej zarysie zbliżone do tego, o co walczyli rebelianci na Wyspach Brytyjskich 500 lat wcześniej.

Najprawdopodobniej dlatego chłopi, którzy od uwłaszczeń przeprowadzanych przez kolejnych zaborców mogli funkcjonować w gospodarce coraz bardziej wolnorynkowej, a którzy po 1918 r. uczestniczyli także w wolnym rynku politycznych idei (na którym to rynku mieli silną reprezentację swych interesów), zarzucili jakiekolwiek monarchistyczne sentymenty i raczej stali po stronie sił, broniących swobód demokratycznych. Zatem program Związku Młodej Polski Ludowej i o dekadę późniejszy, Zjednoczenia Ludowego pozostają co najwyżej interesującą pozostałością odchodzących w cień idei, a zarazem dowodem na silny ruch myśli w łonie tych, którym marzyła się Polska Ludowa jako realizacja planu modernizacji, wiodącego w kierunku powstania kraju wolności i sprawiedliwości społecznej.

26 W. Witos, Moje wspomnienia. Część I, A. Czubiński (red.), Warszawa 1978, s. 85.

27 Tamże, s. 87

28 Tamże, s. 90

29 A. C. Dobroński, Wydarzenia 1905-1907 roku i ich skutki, [w:] J. Gmitruk, R. Szydlik (red.), ,"Siewwa" 1906-1908, Warszawa 2010, s. 28.

30 Tamże, s. 32.

31 W. Witos, Moje zuspomnienia. Cześć II, dz. cyt., s. 29.

32 R. H. Hilton i H. Fagan pisali: „Złudzenia chłopów co do monarchii miały swoje podstawy historyczne. Były nimi reminiscencje z okresu monarchii plemiennych, gdzie królowie i szlachta bardzo mało różnili się od wolnych członków plemienia. Przywódcy wojowników otoczeni byli jedynie większymi honorami oraz składano im dobrowolną daninę. Co jednak ważniejsze, władzę państwową w ustroju feudalnym - jak zresztą we wszystkich innych ustrojach państwa klasowego aż do współczesnego nam włącznie - przedstawiano zawsze jako siłę bezstronna, ponadklasowa, godzącą sprzeczne interesy społeczne. Mówiono, że król jest źródłem wszelkiego prawa, lwem sprawiedliwości, pogromcą złoczyńców i opiekunem słabych". Zob. R. H. Hilton, H. Fagan, Powstanie angielskie 1381 r., Kraków 1951, s. 216. 


\section{Bibliografia}

\section{Teksty źródłowe}

[1] 1907, styczeń, Program pt. „Związek Młodej Polski", opracowany przez grupẹ ludowców skupiony wokót pisma "Siewba”, [w:] Dunin-Wąsowicz K. Kowalczyk S., Molenda J., Stankiewicz W. (red.), Materiaty źródtowe do historii polskiego ruchu ludowego, T. I, Warszawa 1966.

[2] 1915, Warszawa, Program Zwiazku Chłopskiego, [w:] Dunin-Wąsowicz K., Kowalczyk S., Molenda J., Stankiewicz W. (red.), Materiaty źródłowe do historii polskiego ruchu ludowego, T. I, Warszawa 1966.

[3] 1917, Warszawua, Program Zjednoczenia Ludowego, [w:] Dunin-Wąsowicz K., Kowalczyk S., Molenda J., Stankiewicz W. (red.), Materiały źródlowe do historii polskiego ruchu ludowego, T. I, Warszawa 1966.

\section{Książki/czasopisma}

[4] Ciołkosz A., Ciołkosz L., Zarys dziejów socjalizmu polskiego, T. I, Londyn 1966.

[5] Dobroński A. C., Wydarzenia 1905-1907 roku i ich skutki, [w:] Gmitruk J., Szydlik R. (red.), ,"Siewba" 1906-1908, Warszawa 2010

[6] Fagan H., Hilton R. H., Powstanie angielskie 1381 r., Kraków 1951.

[7] Laskowski P., Szkice z dziejów anarchizmu, Warszawa 2007

[8] Mickiewicz A., Księgi narodu i pielgrzymstwa polskiego, Warszawa 1986.

[9] Piskała K., Zapomniana rewolucja, [w:] Marzec W., Piskała K. (red.), Rewolucja 1905. Przewodnik Krytyki Politycznej, Łódź 2013.

[10] Topolski J., Świat bez historii, Poznań 1998

[11] Witos W., Moje wspomnienia. Czẹść I, Czubiński A. (red.), Warszawa 1978.

[12] Witos W., Moje wspomnienia. Część II, Karczewski E., Szaflik J.R. (red.), Warszawa 1990.

\section{Netografia}

[13] BORN IN THE PRL, https://www.facebook.com/BornInThePRL?fref=ts, 1.12.2013.

[14] Okraska R., Za szczéście wasze i nasze, czyli polska teologia wyzwolenia, http://lewicowo.pl/za-szczescie-wasze-i-nasze-czyli-polska-teologiawyzwolenia/, 1.12.2013.

[15] Pierwsza programowa odezwa Polskiego Związku Ludowego, http://lewicowo.pl/pierwsza-programowa-odezwa-polskiego-zwiazku-ludowego/, 1.12 .2013$. 